\title{
A Content Analysis Study towards Researches Regarding Context-Based Learning Approach in Science Education by Between Years 2010 and 2020 in Turkey
}

\author{
Büşra Arik Güngör ${ }^{1 *}$, Mustafa Metin², Sibel Saraçoğlu² \\ ${ }^{1}$ Talas Çömlekçi Middle School, Turkey \\ ${ }^{2}$ Erciyes University, Department of Mathematics and Science, Turkey \\ *Corresponding Author. busrarik38@gmail.com
}

\begin{abstract}
The purpose of this study is to study research regarding the context-based learning approach in science education between 2010 and 2020 in Turkey. In this study, a descriptive content analysis method was used to analyzed 86 articles on contextbased learning in science education published in 67 different journals. According to some variables such as the year of publication, purpose, area, method, sample, number of samples, data collection tool and data analysis techniques. The Research Classification Form developed by the researchers was used in the analysis of the data. The data were analyzed using descriptive content analysis. Most studies in the field of context-based learning approaches in science education were published in 2019. Most of the studies aimed to determine the effects of the method on achievement and attitude and were carried out within science. The experimental method was preferred among the quantitative methods in the studies. Most of the studies were conducted with secondary school students, and the number of participants was in the range of 0-100. Achievement tests and attitude scales were used extensively as data collection tools, and content analysis and t-test were used extensively in data analysis techniques. According to the results obtained in the research, it is suggested that the researches on the context-based learning approach should be conducted in areas other than science education.
\end{abstract}

Keywords Science Education, Life-Based Learning, Context-Based Learning, Content Analysis

\section{INTRODUCTION}

Today, the scientific literacy level of individuals has become an indicator of the development of countries together with rapidly developing technology and changing scientific knowledge (Can \& Çelik, 2020). This situation has revealed the need to raise individuals who use science and technology and apply the recipe with what is given to them and develop science and technology and create new recipes. Therefore, the needs of individuals have also changed during recent years, and using the knowledge efficiently has become more valuable. Therefore, it is needed to prevent disconnection between learned knowledge and daily living in schools, and students should be able to solve problems met in their daily lives by using the knowledge they have learned in classes (Dewi, Poedjiastoeti \& Prahani, 2017; Oduor, 2013; Sugiono \& Purwastuti, 2017).

Especially science education has great importance for transferring knowledge into daily living situations among educational programs (Aikenhead 2006; Rosa, Mundilarto,
Wilujeng \& Sulistyani, 2019; Tal \& Dierking, 2014). However, it is stated that students couldn't find an answer to what the science concepts learned in the course would do in their daily lives and that they couldn't associate the concepts learned with daily life events. This situation causes a reduction of the interest of students in the lesson, having difficulties in learning, and decrease in performance (Aniashi, Okaba, Anake \& Akomaye, 2019; Balkan Kıyıc1 \&Aydoğdu, 2011; Gilbert, 2006; Stolk, Bulte, De Jong \& Pilot, 2009; Yıldıım, Küçük \& Ayas, 2013). To overcome these problems, the use of education programs allowing students to build more association with the world they are living in and to be able to use learned in different situations carries importance (De Jong, 2008; Genç, Ulugöl \& Ünsal, 2017, MEB, 2020).

Thus, it is necessary to use learning approaches that include practices attracting children's attention and

Received: 28 March 2021

Revised: 30 April 2021

Published: 1 March 2022 
intriguing, contribute to the integration of the learned subject with daily life and improve not only knowledge but also skills, abilities, and capacities. (Çepni, Özmen \& Ayvac1, 2015; Flynn, 2019; How Kids Learn Science Best, 2021; Rosa, Mundilarto, Wilujeng \& Sulistyani, 2019; Silander 2015). Moving from these requirements, the thought of using a context-based learning approach, foundations of which are based on social structuring in educational programs, has appeared (Çepni, Özmen \& Ayvac1, 2015). In this context, in the early 1980s, a group of chemistry educators from York University started to use real-life fiction called Salters stories as a way to achieve their learning goals, and when successful results were achieved, the use of this approach was widespread in many countries (Bennett \& Lubben, 2006; Ramsden, 1997; University of York, 2015).

The purpose of the context-based learning approach is to provide students' learning by associating their previous knowledge and experiences in daily life. The context-based learning approach defends the thought that learning is beneficial only in case based on real-life and performed with strong interactions (Cobos, Castilla \& López, 2017; Çepni, Özmen \& Ayvac1, 2015). In context-based learning approach, learning desires and efforts of students are tried to be increased by providing awareness between situations in their daily lives and science in a learning process occurring in a social environment, which supports teaching and learning (Demir, 2019; Gilbert, 2006; King, Winner \& Ginns, 2011; Sevian, Dori \& Parchmann, 2018). Contextbased learning is a contemporary learning approach that excites students, facilitates understanding of concepts and principles related to a subject by students, increases students' motivations during the active learning process, and allows students to take responsibility through individual learning. Besides, this approach supported that students make them gain self-management skills, increases superior thinking, communication skills of students, provides an increase of interests of students, teachers towards lessons and at the same time, considers scientific developments (Gilbert, 2006; Kutu \& Sözbilir, 2011; Overton \& Potter, 2011; Özay-Köse, \& Çam Tosun, 2011).

It is seen in the literature searching that many national and international studies have been conducted related to context-based learning approach, which showed many positive influences in learning and teaching (Bellocchi, King \& Ritchie, 2016; Gül \& Konu, 2018; John, Molepo \& Chirwa, 2018; Karsl1-Baydere \& Kurtoğlu, 2020; Podschuweit \& Bernholt, 2018; Tulum, 2019; Yıldırım \& Dağ1stanl, 2020; Wiyarsi, Pratomo \& Priyambodo, 2020). When conducted research is examined, it is seen that subject areas, purposes, methods, data collection tools, and study groups of studies differ from each other, and each one should be solved separately. Concurrent access to researches on this subject, reading, interpretation, and solving difficulties suggest the requirement for researches based on integrated analysis on this area. Although review studies carried out regarding context-based learning approach, it takes attention that their number is quite limited (Kabuklu \& Kurnaz 2019; Ültay \& Ültay, 2014). Investigation results, including integrated analyses related to the context-based learning approach, will summarize contemporary studies in the related area and facilitate researchers, teachers, and other shareholders to research data related to the subject area. Critical data to be presented about the content of studies being conducted on this subject would present a possibility to researchers for seeing new and different studies in an integrated way on this subject. It would contribute to developing different viewpoints about the subject.

Moreover, it is expressed in the MEB 2023 vision document that the science course curriculum should be designed to raise individuals who do not see what they learn as independent from the life they live and who can offer solutions to the problems encountered in daily life (MEB, 2020). Therefore, research results to be made in this context may also contribute to drawing the attention of program preparers on this issue. Considering this fact, it is essential to conduct a holistic analysis of studies in which context-based learning approach is investigated from different perspectives.

This study aims to conduct a content analysis of research regarding the context-based learning approach in science education between 2010 and 2020 in Turkey. Within this context, answers to the following questions were sought in the research:

Of researches with the subject of context-based learning approach in science education; i) How are their distribution according to $i$ ) years, ii) purpose, iii) study area, iv) approach/methods of research, v) sample group; vi) sample size, vii) data collecting tools and viii) data analysis methods?

\section{METHOD}

This study aims to conduct content analysis articles published in Turkey between the years 2010-2020 related to the context-based learning approach in science education. Content analysis is considered in three categories as meta-analysis, meta-synthesis, and descriptive analysis in the literature (Çalık \& Sözbilir, 2014). Within this study, descriptive content analysis method has been used to determine the general trend in research where both quantitative and qualitative research methods were used (Cohen, Manion \& Morrison, 2007). Similar data are combined within the frame of specific concepts and themes with the descriptive content analysis method. Finally, they are arranged and interpreted in a way that the reader can understand (Fraenkel, Wallen \& Hyun, 2012).

\subsection{Population and Sample}

The sample of this research is formed by articles published in Turkey between 2010 and 2020 years related 
to the context-based learning approach in science education. While the sample of the research was selected; it was taken into consideration criteria such as executed study is in Turkey, it is present in Ulakbim and TR index, it can be accessed as a whole text in Google Academy database, and it would contain keywords of "bağlam temelli öğrenme", "yaşam temelli öğrenme", "context-based learning" and "life-based learning". By taking these criteria into consideration, a sample of our research consists of 86 articles published in 67 different journals comprising studies until 30.11.2020.

\subsection{Data collection tool}

A "Research Examination Form" has been developed to evaluate articles related to the context-based learning approach in science education within the study context, and this form has been used as a data collection tool. While developing research examination form, studies previously executed by descriptive content analysis in the literature have been investigated (Akkuş, Sar1 \& Uner, 2012; Chang, Chang \& Tseng, 2010; Keklik, 2011; Kızılaslan, Sözbilir \& Yaşar, 2012; Selçuk, Palanc1, Kandemir \& Dündar, 2014) and features that should be present in a scientific article have been examined (Büyüköztürk et al., 2014; Cohen, Manion \& Morrison, 2007; Çepni, 2012; Fraenkel, Wallen \& Hyun, 2012). In line with examinations made, there are nine chapters as the masthead, year, purpose, study area, approach/method, sample group, sample size, data collection tools, and data analysis techniques. Categories included in this examination form and options to be given under this category have been presented to the opinions of two experts studying in the area of content analysis. Arrangements have been made in the form in line with expert opinions.

\subsection{Data analysis}

86 articles complying with criteria determined within the study context have been analyzed according to the research examination form developed by researchers. Two different researchers have separately evaluated the studies by considering categories determined in the form in the analysis of articles. Researchers have recorded findings obtained from articles in a Microsoft Excel file and categorized them within the research questions frame. After the analysis of all the articles was completed, the two researchers' analyses were compared, and the analysis data were arranged in line with a common opinion. Findings obtained are then presented in the form of tables and graphs. After the analysis, the data were organized, and inferences were made.

\section{RESULT AND DISCUSSION}

86 articles published between the years 2010-2020 in the context-based learning approach in science education, of which whole text could be accessed, have been analyzed, and findings have been presented in the form of separate graphics within the context of determining categories. The distribution of studies examined according to years has been presented in Figure 1.

When the distribution of articles in the area of contextbased learning according to years given in figure 1 is examined, it is seen that 16 articles were published in 2019, 15 articles in 2017, two or three studies in 2010 and 2014. Thus, it is seen that articles published in the area of contextbased learning showed an increase during recent years.

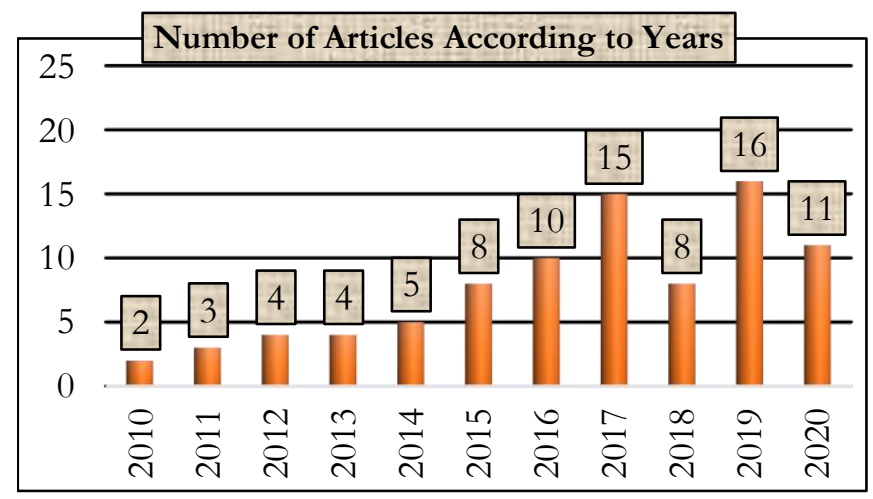

Figure 1 Distribution of articles examined in the area of context-based learning in science education according to years

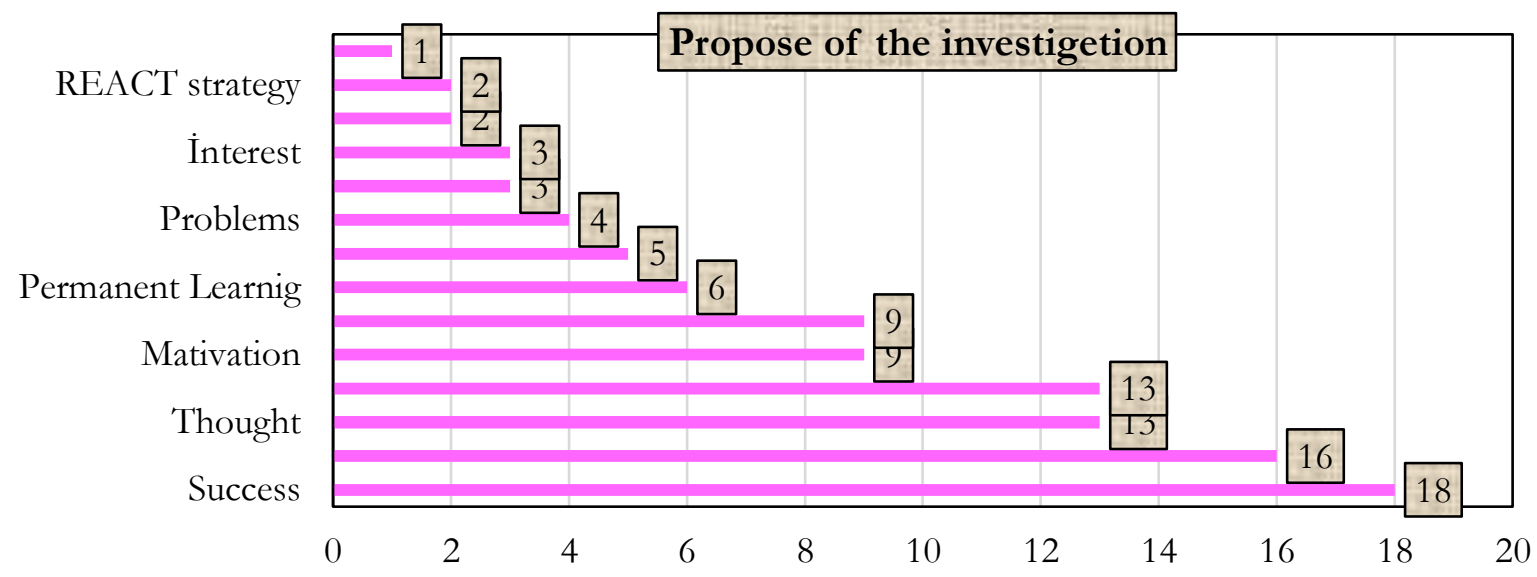

Figure 2 Distribution of articles examined in the area of context-based learning in science education according to purpose 
The distribution of examined articles according to purpose has been given in Figure 2. When figure 2 is examined, it is seen that 18 studies conducted in the field of context-based learning are aimed at determining the effect of this method on success, and 16 of them are aimed at determining the effect on attitude. In addition, the opinion of the context-based learning sample was determined in 13 studies, and 13 studies were conducted to determine the effect of context-based learning on the sample's conceptual understanding.

The distribution of examined articles according to subject areas they are included has been presented in figure 3 . When figure 3 is examined, a more significant majority (49 articles) of subject areas of studies conducted related to subject of context-based learning have been included in the subject area of science. For example, it has been seen that

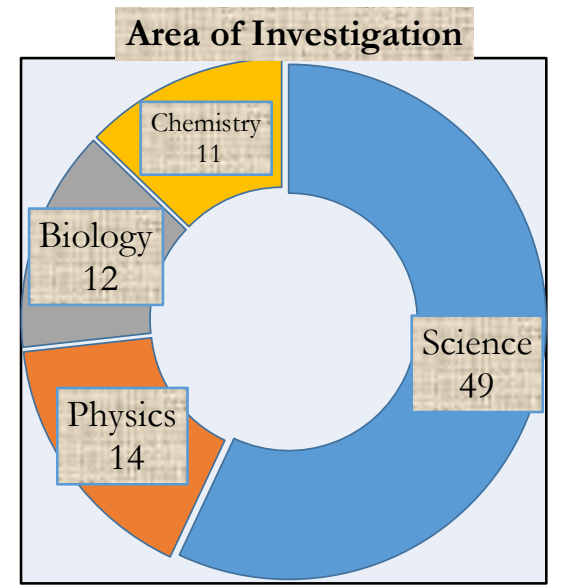

Figure 3 Distribution of articles examined in the area of contextbased learning in science education according to subject areas
14 scientific studies have been made in physics education, 12 in biology education, and 11 in chemistry education.

Distribution of examined articles according to approach and method of research used has been given in Figure 4. When figure 4 is examined, quantitative research method has been used in 53 articles, qualitative research method in 26 articles and mixed research method in 7 articles published between years 2010-2020. It has been determined that the most preferred method in studies where a quantitative research approach was used is the experimental research method with 42 studies. Besides, it is understood from figure 4 that the most used qualitative research approach is the status study method with 11

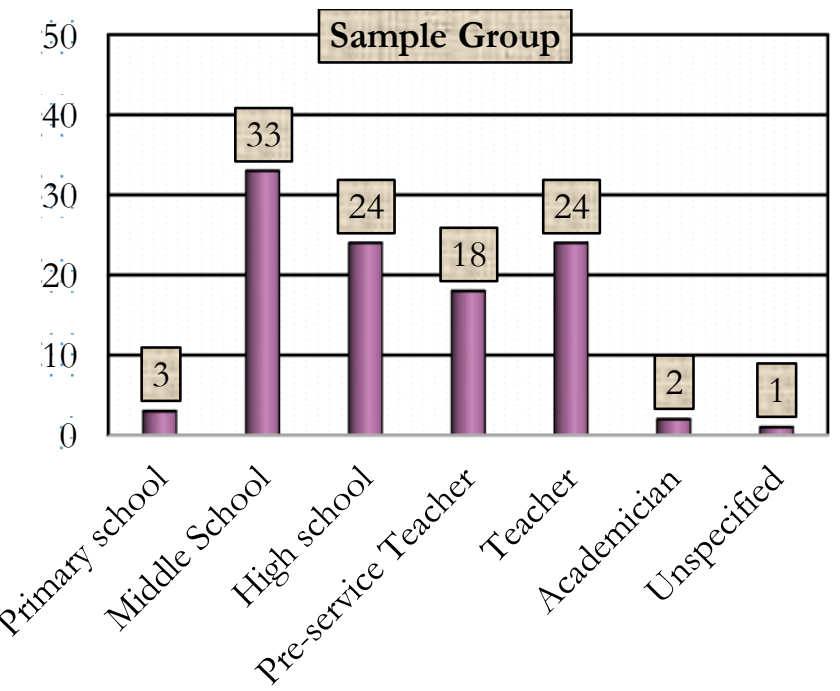

Figure 5 Distribution of examined studies according to sample group

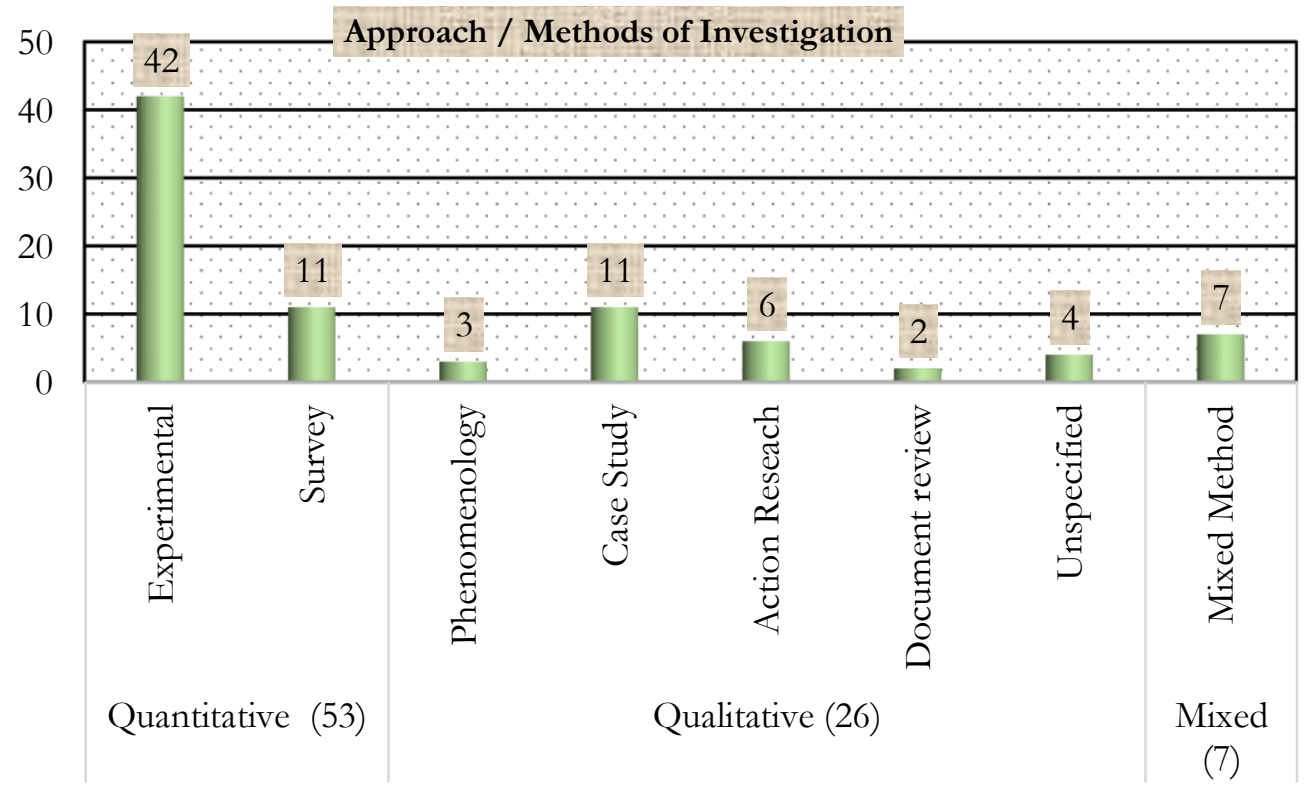

Figure 4 Distribution of studies examined in the area of context-based learning in science education according to approach and method of investigation 
studies. However, in mixed studies, it is seen that methods are generally not specified, and they are expressed only as "mixed method was used".

Distributions of examined articles according to sample groups included in the study have been given in Figure 5. When we look at figure 5 , it is seen that 33 percent of researches have been conducted on middle school students. Also, it has been determined that 24 types of research have been performed with high school students and teachers. However, it is seen in the research that preservice teacher were chosen as a sample in 18 studies and primary school students in 3 studies, and academicians in 2 studies.

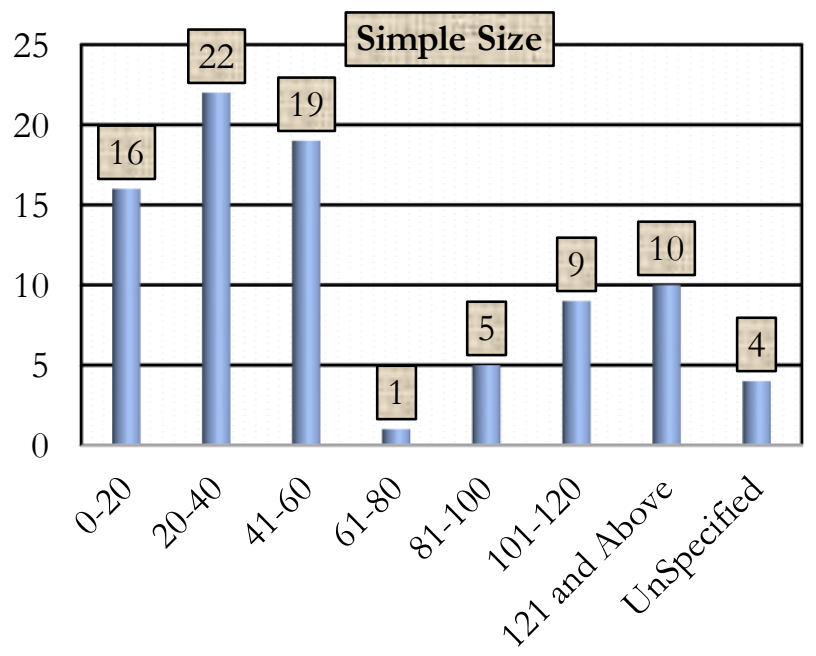

Figure 6 Distribution of studies examined in the area of context-based learning in science education according to participant number in their samples
The distribution of examined articles according to sample size included in the sample group where studies were conducted has been presented in figure 6 . When figure 6 is examined, 22 studies have $21-40$ participants, 19 studies with 41-60 participants, 16 studies with 0-20 participants, and ten studies with 121 and more participants. Therefore, it was determined that most researches (63 types of research) had been conducted with a sample size between the range of 0-100.

The distribution of data collection tools used in examined articles has been given in figure 7 . When the distribution of data collecting tools given in figure 7 is examined, the number of data collecting tools is more than a number of examined articles because more than one data collecting tool has been used in some studies. When figure 7 is examined, it is understood that the questionnaire was chosen in 10 studies, scale in 34 studies, and 39 studies and form in 27 studies. It is observed that primarily open-ended questionnaires (8) were used in studies where the questionnaire was used and that mostly attitude scales (17) were used in studies where scales were used. Also, while mostly success tests (27) were preferred in research where the test was used, mostly interview forms (16) were used among forms.

The distribution of analysis methods of data used in examined articles has been given in figure 8 . When figure 8 is examined, it is seen that content analysis / descriptive analysis was used in the greater majority of studies with 32 studies and that t-test was used in 30 studies. Also, it is determined that Anova was used in 9 studies, MannWhitney $\mathrm{U}$ test in 9 studies, and ANCOVA analysis in 4 studies

This research aims to conduct a content analysis on articles published in Turkey between 2010-2020 on the

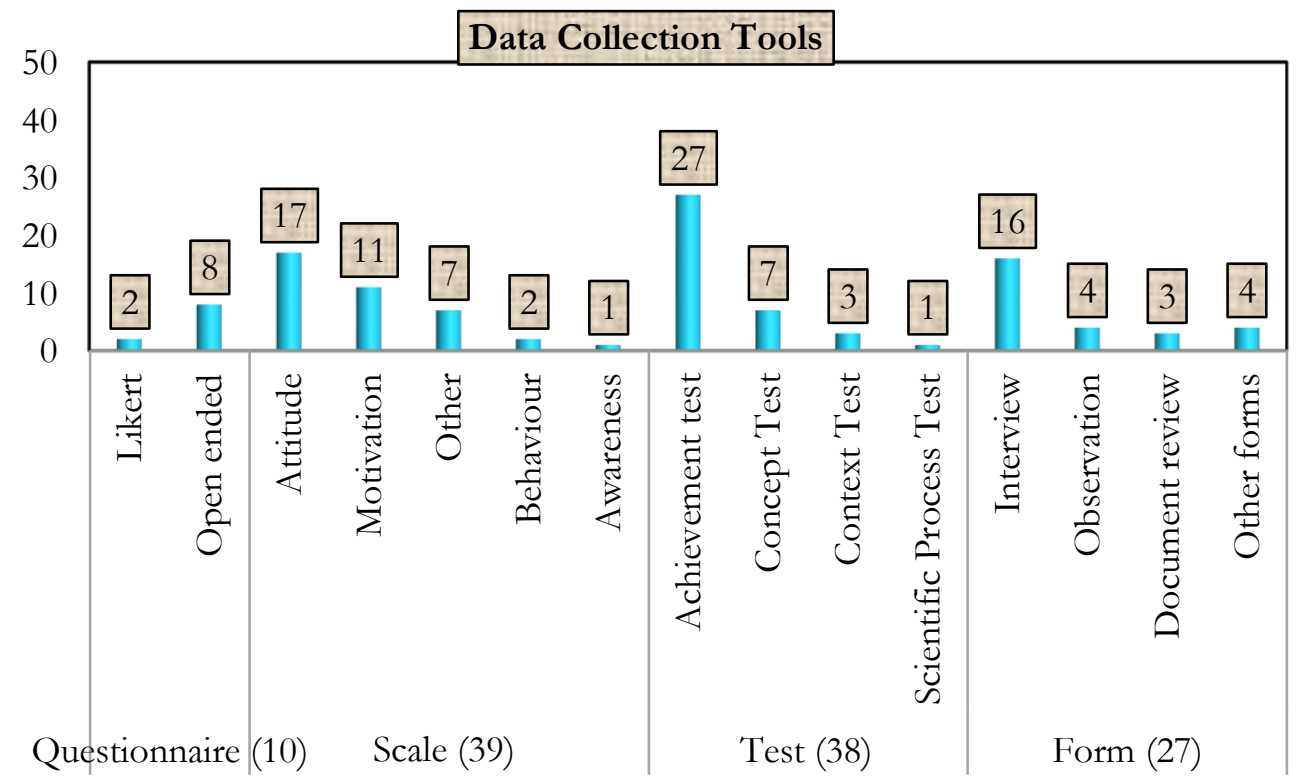

Figure 7 Distribution of studies examined in the area of context-based learning in science education according to data collecting tools 


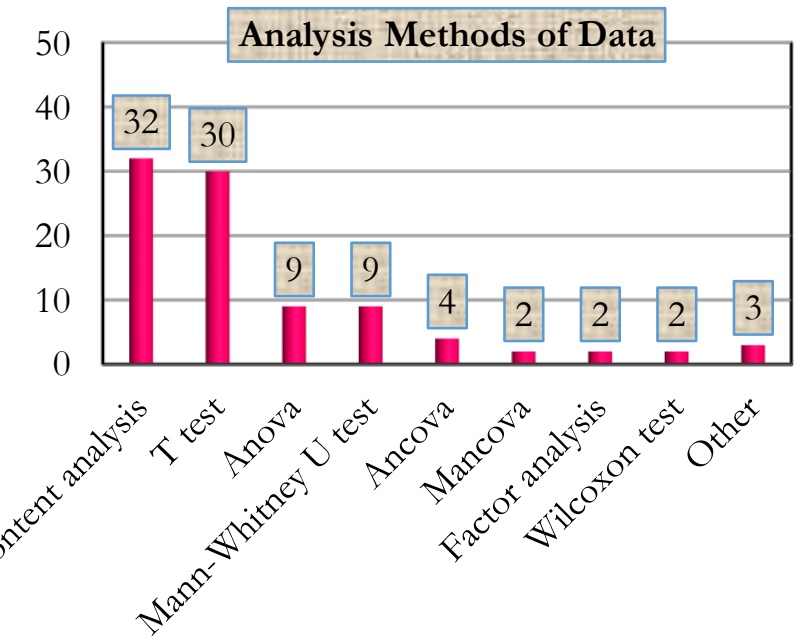

Figure 8 Distribution of studies examined in the area of context-based learning in science education according to data analysis methods

subject of context-based learning in science education. Within this context, 86 articles published in 67 different journals have been analyzed. Furthermore, research findings have been evaluated under determined categories considering analysis data.

The first of these categories is the distribution of particles according to years. Although studies related to context-based learning have started in the 1980s in the international area (Bennett \& Lubben, 2006), it takes attention that two studies taking this approach as a subject in science education has been ma de in 2010 in Turkey. The number of studies that were limited until 2014 on this subject has increased until 2017, and most researches were performed in 2019. Though a reduction was seen in 2020, it is thought that this result has originated from that studies published until November 2020 have been included in the research. When studies of which printing has been completed after November 2020 were considered, possibly the number of related studies would be more than indicated. One of the reasons for the increase of studies related to context-based learning may be that this subject has been given more importance in programs. Thus, it is indicated that education programs of science that was renewed in line with MEB 2023 vision have been structured such as individuals can present solutions for problems they met in their daily lives, that they don't see learned things independent of the life, they lived and that they would have gained for putting forward new technological products in line with their needs (MEB, 2020). One of the most suitable approaches that facilitate accessing to indicating gains is context-based learning. It aims to update undergraduate for Science Teachership to develop candidates' abilities for context-based science teaching (YÖK, 2018).
For this reason, the use of this approach has gained importance in science education, and the need for evaluating problems and solutions came by use of this approach could have directed researchers to this subject. Also, this approach found more place in renewed programs causes more activities to be developed in science education. This situation requires performing more researches on this subject. It is expected that the use of context-based science education, many advantages of which have been expressed in the literature (Demircioğlu, Vural \& Demircioğlu, 2012; Gilbert, 2006; Sözbilir, Sadi, Kutlu \& Yıldırım., 2007), would become widespread and increase in several types of research on this subject.

Another category formed as a result of research findings is the distribution of researches according to purpose. On examinations made, it is seen that researches related to context-based learning approach have focused on the subject of the influence of context-based learning approach on the success of students and their attitudes towards science lessons. Subjects following them are participants' thoughts related to this approach and the effect of conceptual understanding. The context-based learning approach aims to provide awareness of students on the association of real-life issues and science by presenting scientific concepts to students together with events selected from daily life and thus, to increase desire and motivations of students for learning (Çepni, 2012; Kutu \& Sözbilir, 2011; Özay-Köse, \& Çam Tosun, 2011). Increased desire and motivation of students contribute to increasing their interest in science and their academic performances (Çepni, 2012; Gilbert 2006, Sözbilir et al., 2007). Within this context, it is an expected result that researchers have given more places to the status of accessing targets of this approach in their researches. But, it is seen in the literature that several studies related to perception and awareness related to context-based learning are pretty limited. Awareness of teachers/teacher candidates/students related to the approach used influences the quality of teaching and learning (Yakar \& Duman, 2017). This situation brings the requirement for making more studies on this subject into the schedule. No study hasn't been met in the literature examination related to context-based science education on students' abilities such as communication, social, and entrepreneurship. However, this approach is based on cooperation built between concepts and daily living and covers a process occurring in a social environment that supports learning (Gilbert, 2006). Obtained results and literature data show a need for studies examining the effects of context-based science education on high-level skills such as social skills, creativity, and entrepreneurship. Therefore, the fact that there is no study on this subject in the literature is considered a deficiency.

When researches examined within the context of the research are analyzed, it is seen that the more significant majority of researches have been in the area of science. 
When the objectives of the science course curriculum and the characteristics of the context-based learning approach are examined, it is seen that one of the most appropriate approaches that can be used to achieve these goals is context-based learning (Coştu, 2009; Gilbert, 2006, MEB, 2020). This situation may be one of the causes why the subject area of science is more involved in researches. The fact that the target audience examined in the studies is mostly at the secondary school level may have caused such a result in the subject area.

When examined in terms of research approach and methods used in studies on context-based learning approach in science education in the literature, it is seen that primarily quantitative research approach and empirical method are used. Still, qualitative and mixed methods are also included. While the experimental method is used in $49 \%$ of the research examined, the mixed method ratio remains at $8 \%$. The number of researches using case science, action research, and document examination methods is also limited. The fact that experimental researches completely put forward the cause-result association may lead to this result. Because experimental researches are interventional researches and also giving education to individuals would be considered an intervention, researchers could have preferred this method in their researches (Özmen, 2014). But, it can be indicated that increasing qualitative and mixed research is needed to perform in-depth research. When researches are evaluated for sample groups, it is seen that researches have been primarily conducted with secondary school students. This situation shows parallelity with the result that most studied area has been science education. Secondary school level is a period of physical, mental-emotional changes in individuals. These changes may reveal some academic and psychological problems. Schools have an essential role in using appropriate approaches that touch young people's lives, reduce their anxiety, meet their desire to join a group, interest, curiosity, and motivation for healthy academic, social, and emotional development (Sirin, 2020). During this period, youth having required environmental support can solve their problems more efficiently. When characteristics of this age group and aims of context-based learning and science lesson program are taken together, it wouldn't be surprising that the number of studies towards this age group is higher. A context-based learning approach is also recommended in the updated science program (MEB, 2020). Indicated situations may be a justification of the abundance of researches numbers at the secondary school level. Several studies conducted on primary school students is quite limited in studies. Due to the effects of approaches used in schools on the behavioral changes of individuals, evaluating the influence of this approach in younger age groups could make essential contributions for researchers and executers for the aspect of revealing the advantages and limitations of the approach.
When studies are examined according to the sample size, most studies have been conducted with participants between a range of 0-100. Most studies have been performed with participants ranging from $20-40$ people. It is thought that a lower number of samples in studies is influenced by the fact that the experimental method of quantitative approach has been used chiefly, and a high number of researchers have preferred qualitative research methods. Due to some ethical issues and a small number of students in a class where the application would be made, a study has been conducted with a sample of a limited number (Büyüköztürk et al., 2014; Fraenkel, Wallen \& Hyun, 2012; Özmen, 2014). Similarly, in studies where qualitative research methods have been used, a sample with a limited number is preferred due to lack of anxiety of generalization of research result and to investigate the subject more in-depth (Cohen, Manion \& Morrison, 2007; Fraenkel et al., 2012; Yıldırım \& Şimşek, 2006). When these two situations are considered, it is seen that being sample in a limited number is unavoidable. In the investigation performed for the aspect of data collecting tools used, the number of data collecting tools is higher than the number of researches. This situation originated from the use of more than one data-collecting tool to increase validity in research. Mainly used data collecting tools in research are achievement test, attitude and motivation scale as scale, and interview method as form and open-ended questionnaires. This situation overlaps with the result that the methods used have been primarily quantitative. The finding that the interview method is the most used data collecting tool in qualitative studies (Yıldırım \& Şimşek, 2006) supports the result of research. Interview forms have been chiefly used for supporting quantitative data. It is seen that the aims of examined researches and findings related to data collecting tools used have supported each other.

When obtained results are evaluated for data analysis techniques, it takes attention that mostly content analysis and t-test have been used. Several types of research where other analysis techniques have been used are pretty limited. When examined researches are considered, it is observed that data collection tools, by which qualitative findings are obtained, such as observation and interview form, using in both qualitative and mixed research methods. In this case, solving data obtained in the study by using content analysis is a natural situation. It is expressed in qualitative research methods that data have been solved descriptively by creating a specific theme and codes and more detail by making content analysis (Çepni, 2012; Yıldırım \& Şimşek, 2006). It is seen that another mostly chosen data analysis method is the independent $t$-test within the context of the study. Non-parametric analyses such as dependent and non-dependent t-test, Anova, Ancova, Manavo, Mancova, Chi-square test, Mann-Whitney test, Wilcoxon signed-rank sum, and sign test are used in the analysis of data in studies in which experimental research methods are used (Metin, 
2014). In research examined within the context of the study, t-tests have been used to show the normal distribution in experimental research. They have more strong validity for making generalizations compared to results obtained from other non-parametric tests and descriptive analyses (frequency, percent, arithmetic average, standard deviation) (Büyüköztürk et al., 2014; Fraenkel, Wallen \& Hyun, 2012; Metin, 2014). It is thought that obtaining this result is natural. However, nonparametric tests are likely chosen less because they have no normal distribution and weaker validity than parametric tests (Çepni, 2012; Erdem, 2011; Metin, 2014). Investigations performed within the context of the study show parallelity with this situation. Besides, it is observed in the study that advanced statistical analyses such as ANOVA, ANCOVA, Manavo, Mancova, and factor analysis haven't been preferred too much. It is thought that this situation has originated from that research subject isn't suitable for these types of analyses or that researchers aren't competent enough on advanced statistical methods.

\section{CONCLUSION}

In this study, a descriptive content analysis method was used to analyzed 86 articles on context-based learning in science education published in 67 different journals according to some variables such as the year of publication, purpose, area, method, sample, number of samples, data collection tool and data analysis techniques. Most studies in the field of context-based learning approaches in science education were published in 2019. Most of the studies aimed to determine the effects of the method on achievement and attitude and were carried out within science. The experimental method was preferred among the quantitative methods in the studies. Most of the studies were conducted with secondary school students, and the number of participants was in the range of $0-100$. Achievement tests and attitude scales were used extensively as data collection tools, and content analysis and t-test were used extensively in data analysis techniques.

The following recommendations can be presented based on the results achieved:

Within the scope of this study, researches on the context-based learning approach in science education were examined. It may be suggested to other researchers researching this field to examine the studies on contextbased learning approaches in different disciplines. In addition, since the number of studies at the primary school level is limited, it is believed that conducting studies with primary school students will contribute to the field. Besides, it is seen that studies are conducted with a limited number of participants. Therefore, quantitative studies with a large number of participants are recommended. Furthermore, more emphasis can be placed on quantitative or mixed research to make more detailed and in-depth research. Also, it can be suggested that comprehensive studies using different analysis techniques such as bibliometric analysis can be conducted.

\section{REFERENCES}

Aikenhead, G. S. (2006). Science education for everyday life, Canada, Teachers College Press.

Akkus, H., Sari, S. N., \& Uner, S. (2012). The content analysis of graduate theses written between 2000 and 2010 in the field of chemistry education. Procedia-Social and Behavioral Sciences, 47, 729733.

Aniashi, S. O., Okaba, L. A., Anake, E. U., \& Akomaye, M. U. (2019). Classroom science with everyday life: A means for improving performance in sciences and national development in Nigeria. International Journal of Science and Technology Education Research, 10(3), 25-29.

Balkan-Kıyıc1, F. \& Aydoğdu, M. (2011). Fen bilgisi öğretmen adaylarının günlük yaşamları ile bilimsel bilgilerini ilişkilendirebilme düzeylerinin belirlenmesi [Determining the level of associating science teacher candidates' daily life with their scientific knowledge.]. Necatibey Eğitim Fakültesi Dergisi, 5(1), 43-61.

Bellocchi, A., King, D. T., \& Ritchie, S. M. (2016). Context-based assessment: Creating opportunities for resonance between classroom fields and societal fields. International Journal of Science Education, 38(8), 1304-1342.

Bennett, J. \& Lubben, F. (2006). Context-based chemistry: The Salters approach. International journal of science education, 28(9), 999-1015.

Büyüköztürk, Ş., Kılıç Çakmak, E., Akgün, Ö.E., Karadeniz, Ş. \& Demirel, F. (2014). Bilimsel araştirma yöntemleri [Scientific research methods 7 (17. Baskı). Ankara: Pegem Yayınları

Can, S.. \& Çelik, C. (2020). Pre-Service science teachers' universal science literacy levels across the statistical regional units. Pamukeale Üniversitesi Ë̆itim Fakültesi Dergisi, 49, 112-133.

Chang, Y. H., Chang, C. Y., \& Tseng, Y. H. (2010). Trends of science education research: An automatic content analysis. Journal of Science Education and Technology, 19(4), 315-331.

Cobos, T. L., Castilla, R. L., \& López, Á. B. (2017). Procesos de oxidación: Un acercamiento a su estudio en la ESO [Oxidation processes: An approach to its study at ESO]. Boletín ENCIC: Revista del Grupo de Investigación HUM-974, 1(1), 7-8.

Cohen, L., Manion, L., \& Morrison, K. (2007). Observation. Research methods in education, 6, 396-412.

Coştu, S. (2009). Matematik ögretiminde bağlamsal ögrenme ve ögrretme yaklassmmna göre tasarlanan ögrenme ortamlarnda ögretmen deneyimleri. Teacher experiences in learning environments designed according to the contextual learning and teaching approach in mathematics teaching]. (Unpublished master's Thesis). KTÜ Fen Bilimleri Enstitüsü, Trabzon.

Çalık, M. \& Sözbilir, M. (2014). İçerik analizinin parametreleri [Parameters of content analysis]. Eğitim ve Bilim, 39(174).

Çepni, S. (2012). Araştırma ve proje çalssmalarna giriş [Introduction to research and project work]. Ankara: PegemA Yayincilik

Çepni, S., Özmen, H., \& Ayvacı, H. Ş. (2015). Yaşam (bağlam) temelli, beyin temelli öğrenme kuramları, 21. Yüzyıl becerileri ve FETEMM yaklaşımı ve fen bilimleri öğretimindeki uygulamaları [Life (context)-based, brain-based learning theories, 21st century skills and STEM approach and its applications in science teaching] . S. Çepni (Ed.), Kuramdan uygulamaya fen ve teknoloji ögretimi içinde, Ankara: Pegem Akademi

De Jong, O. (2008). Context-based chemical education: how to improve it?. Chemical Education International, 8(1), 1-7.

Demircioğlu, H , Vural, S , \& Demircioğlu, G . (2012). "React" stratejisine uygun hazırlanan materyalin üstün yetenekli ögrencilerin başarısı üzerinde etkisi [The effect of the material prepared in accordance with the "React" strategy on the success of gifted students]. Ondokuそ, Mayss Üniversitesi Eg̈itim Fakültesi Dergisi ,31 (2), 101-144 
Demir, İ. (2019). Yasam temelli ögretimin ortaokul 7.sme ögrencilerinin ăgrz ve diş hijjeni konusunda kavram öğrenmelerine, fen bilimlerine karș tutumlarna ve motivasyonlarna etkisi [The effect of life-based teaching on secondary school 7th grade students' learning concepts about oral and dental hygiene, their attitudes and motivations towards science.] [Yayınlanmamış Yüksek lisans tezi]. Marmara Üniversitesi, Eğitim Bilimleri Enstitüsü, İstanbul.

Dewi, I. N., Poedjiastoeti, S., \& Prahani, B. K. (2017). Elsii learning model based local wisdom to improve students' problem solving skills and scientific communication. International Journal of Education and Research, 5(1), 107-118.

Erdem, D. (2011). Türkiye'de 2005-2006 yayımlanan eğitim bilimleri dergilerindeki makalelerin bazı özellikleri incelemesi: Betimsel bir analiz [Analysis of some features of articles in educational sciences journals published in 2005-2006 in Turkey: A descriptive analysis]. Eğitimde ve Psikolojide Ölcme ve Değerlendirme Dergisi , 2 (1), 140-147.

Flynn, S. (2019). Science Literacy - Science Education For Everyday Life, Journal of The Chartered College of Teaching. https://impact.chartered.college/article/science-literacy-scienceeducation-everyday-life/

Fraenkel, W., \& Wallen, \& N. E. Hyun,(2012). How to design and evaluate research in education, (Eight Edition). New York: McGraw-Hill.

Genç, M., Ulugöl, S., \& Ünsal, S. (2017). Ortaokul öğrencilerinin yaşam temelli ögrrenme hakkındaki görüşleri [Secondary school students' views on life-based learning]. Researcher: Social Science Studies, 5(9), 244-255.

Gilbert, J.K. (2006). On the nature of 'context' in chemical education. International Journal Of Science Education, 28(9), 957-976.

Gül Ş. \& Konu M. (2018). Yaşam temelli probleme dayalı öğretim uygulamalarının öğrenci başarısına etkisi [The effect of life-based problem-based teaching practices on student achievement]. Yasadıkça Eğitim, 32(1), 45-68.

How Kids Learn Science Best (2021). https://www.homesciencetools.com/learning-center/how-tolearn-science

John, M., Molepo, J. M., \& Chirwa, M. (2018). Secondary school learners' contextual'zed knowledge about reflection and refraction: a case study from South Africa. Research in Science \& Technological Education, 36(2), 131-146.

Kabuklu, Ü. N. \& Kurnaz, M. A. (2019). Fen eğitimi alanında Türkiye'de yapılmış bağlam temelli öğretim konulu çalışmaların tematik incelemesi [Thematic analysis of studies on context-based teaching in the field of science education in Turkey]. Asya Ögrretim Dergisi, $7(1), 32-53$.

Karsl1-Baydere, F. \& Kurtoğlu, S. (2020). 5. Sınıf öğrencilerinin biyolojik çeşitlilik konusundaki kavramsal anlamalarına REACT stratejisinin etkisi [The effect of REACT strategy on 5th grade students' conceptual understanding of biodiversity]. Yüzüncü Yll Üniversitesi Ë̆itim Fakültesi Dergisi, 17(1), 1015-1041.

Keklik, İ. (2011). Mate Selection Preferences of Turkish University Students. Eurasian Journal of Educational Research (EJER), (44), 129148

King, D. T., Winner, E. \& Ginns, I. (2011). Outcomes and implications of one teacher's approach to context-based science in the middle years. Teaching Science, 57 (2), 26-30.

Kizilaslan, A., Sozbilir, M., \& Yasar, M. D. (2012). Inquiry based teaching in Turkey: A content analysis of research reports. International Journal of Environmental and Science Education, 7(4), 599617.

Kutu, H. \& Sözbilir, M. (2011). Yaşam temelli ARCS öğretim modeliyle 9. sınıf kimya dersi" Hayatımızda Kimya" ünitesinin öğretimi. Ondokuz Mayis University Journal of Education, 30(1), 29-62

MEB. (2020). Illkögretim kurumlar (Ilkokullar ve ortaokullar) fen bilimleri dersi ögretim program [Primary education institutions (Primary and secondary schools) science course curriculum] (3., 4., 5., 6., 7. ve 8. smiflar). Ankara.

Metin, M. (2014). Nicel Veri Toplama Araçları [Quantitative Data Collection Tools]. M Metin (Ed) Kuramdan Uygulamaya Eğitimde Bilimsel Araştrma Yöntemleri (pp.161-214), Ankara: Pegem A Yayınc1lik.
Oduor R (2013). Can Science Solve all the Problems in the World? (For World Science Day for peace and development). http://writeparagraphs.blogspot.com.ng/2013/11/can-sciencesolve-all-problems-inworld.html

Overton, T. L. \& Potter, N. M. (2011). Invesigating students' success in solving and attitudes towards context-rich open-ended problems in chemistry. Chemistry Education Research and Practice, 12, 294-302.

Özay-Köse, E. \& Çam Tosun, F. (2011). Yaşam temelli öğrenmenin sinir sistemi konusunda öğrenci başarılarına etkileri [The effects of lifebased learning on student achievement in the nervous system]. Türk Fen Eğitimi Dergisi, 8(2), 91-106.

Özmen, H. (2014). Deneysel araştırma yöntemi [Experimental research method]. M Metin (Ed) Kuramdan Uygulamaya Eüitimde Bilimsel Arastırma Yöntemleri, (pp.47-76), Ankara: Pegem A Yayıncilık.

Podschuweit, S. \& Bernholt, S. (2018). Composition-effects of contextbased learning opportunities on students' understanding of energy. Research in Science Education, 48(4), 717-752.

Ramsden, J.M. (1997). How does a context-based approach infuence understanding of key chemical ideas at $16+$ ?. Internotional Journal of Science Education, 19, 657-710.

Rosa, F. O., Mundilarto, Wilujeng, I. \& Sulistyani, A. M. (2019). Science In Everyday Life To Build Science Literacy. International Journal Of Sccentific \& Technology Research, 8, 12, 1148-1151.

Sözbilir, M., Sadi, S., Kutu, H., \& Yıldırım, A. (2007). Kimya eğitiminde içeriğe/bağlama dayalı (context-based) Öğretim Yaklaşımı ve dünyadaki uygulamaları [Context-based Teaching Approach in chemistry education and its applications in the world], I. Ulusal Kimya Ë̆itimi Kongresi, 20-22 Haziran, İstanbul.

Selçuk, Z., Palanc1, M., Kandemir, M., \& Dündar, H. (2014). Eğitim ve bilim dergisinde yayınlanan araştırmaların eğilimleri: İçerik analizi [Trends of research published in the education and science journal: Content analysis]. Eğitim ve Bilim, 39(173), 430-453.

Sevian, H., Dori Y. J. \& Parchmann, I. (2018). How does STEM contextbased learning work: what we know and what we still do not know. International Journal of Science Education, 40, 10,1095-1107.

Silander, P. (2015). Rubric for Phenomenon Based Learning. http://www.phenomenaleducation.info/phenomenon-basedlearning.html

Stolk, M. J., Bulte, A. M. W., De Jong, O. \& Pilot, A. (2009). Towards a framework for a Professional development programme: empowering teachers for context-based chemistry education. Chemistry Education Research and Practice, 10, 164-175.

Sugiono, L. R. \& Purwastuti, A. (2017). Local wisdom-based character education model in elementary scgool in Bantul Yogyakarta Indonesia. Sino-US English Teaching Vol.14, No. 5, 299-308. Doi:10.17265/1539- 8072/2017.05.003

Şirin, S. (2020). Yetişin Gençler [Pemuda Dewasa]. İstanbul: Doğan Kitap

Tal, T. \& Dierking L. D. (2014). Learning Science in Everyday Life. Journal of Research in Science Teaching, 51,3, 251-259.

Tulum G. (2019). Fen bilimleri dersi ışı ke konusuna yönelike geliștirilen bağlam temelli materyalin akademik basar üzerine etkisi [The effect of the contextbased material developed for the subject of light in science course on academic achievement]. [Yayınlanmamış Yüksek lisans tezi]. Ondokuz Mayıs Üniversitesi, Eğitim Bilimleri Enstitüsü, Samsun

University of York. (2015). OCR a level salters' advanced chemistry student book. (4th ed.). Oxford: Open University Press. [Google Scholar]

Ültay, E. \& Ültay, N. (2014). Bağlam temelli fizik çalıșmaları: literatürdeki çalışmaların içerik analizi [Context-based physics studies: content analysis of studies in the literature]. Hacettepe Üniversitesi Eğitim Fakültesi Dergisi (H. U. Journal of Education) 29(3), 197-219.

Wiyarsi, A., Pratomo, H., \& Priyambodo, E. (2020). Vocational high school students' chemical literacy on context-based learning: a case of petroleum topic. Journal of Turkish Science Education, 17(1), 147161.

Yakar, A. \& Duman B. (2017). Duyuşsal farkındalığa dayalı öğretimin akademik başarı ve öğretmenlik mesleğine yönelik tutumlar üzerine etkisi [The effect of teaching based on affective awareness on 
academic achievement and attitudes towards the teaching profession.]. Eğitim Kuram ve Uygulama Arasttrmalar Dergisi 3 (3), 30 47.

Yıldırım, H. İ. \& Dağıstanlı, F. (2020). Yaşam temelli öğrenme yaklașımı ile destekli çevre eğitiminin ortaokul 7. sinıf öğrencilerinin çevreye yönelik tutum, davranış ve başarı düzeylerine etkisi [The effect of environmental education supported by life-based learning approach on the attitudes, behaviors and achievement levels of secondary school 7th grade students.]. Mehmet Akif Ersoy Üniversitesi Ë̆itim Fakültesi Dergisi, (54), 106-132.

Yıldırım, N., Küçük, M. \& Ayas, A. (2013). A comparison of effectiveness of analogy-based and laboratory-based instructions on students' achievement in chemical equilibrium. Scholarly Journal of Education, 2(6), 63-76.

Yıldırım, A., \& Şimşek, H. (2006). Sosyal bilimlerde nitel araștırma yöntemleri [Qualitative research methods in the social sciences]. Ankara: Seçkin Yayıncilik

YÖK. (2018). Fen Bilgisi Ögrretmenliği Lisans Program https: //www.yok.gov.tr

/Documents/Kurumsal/egitim_ogretim_dairesi/Yeni-

Ogretmen-Yetistirme-Lisans Programlar1

Fen_Bilgisi_Ogretmenligi_Lisans_Programi.pdf. 